MENELITI KEMBALI TENTANG PUTUSAN MAHKAMAH KONSTITUSI MENGENAI BUPATI TERPILIH SABU RAIJUA 2020 ORIENT RIWU KERU.

ELFIRA NUR FAISHA (10200120253)

\begin{abstract}
Abstrak
Penelitian ini untuk mengetahui putusan mahkamah konstitusi pendiskualifikasian bupati Sabu Raijua terpilih ORIENT RIWU KORE. Dari hasil pengumpulan data dan keterangan dari berbagai pihak, Orient masih terbukti berstatus sebagai warga negara Amerika Serikat (AS). Hal itu diputuskan dalam pembacaan sidang putusan perkara 135/ PHP.BUP-XIX/2021 yang dilayangkan oleh pasangan calon nomor urut tiga Taken Irianto Radja Pono dan Herman Hegi Rdja Haba dalam pilkada Sabu Raijua. Berdasarkan bukti yang dikumpulkan, Mahkamah Konstitusi mengatakan status Orient sejak 2007 adalah warga negara Amerika Serikat (AS). Hal itu dibuktikan dengan kepemilikan paspor Amerika Serikat.

Jika mengacu pada undang-undang Nomor 12 tahun 2006, indonesia menganut asaskewarganegaraan tunggal. Sehingga saat Orient mempunyai paspor Amerika Serikat, saat itu secara otomatis status Warga Negara Indonesia (WNI) tidak berlaku.

Selain itu mengacu pada pasal 7 ayat (1) UU Nomor 10 tahun 2016 terkait persyaratan pencalonan bupati dan wakil bupati mengharuskan berstatus Warga Negara Indonesia (WNI). Sehingga pencalonan Orient tidak dapat diterima.

Mahkamah Konstitusi juga mengatakan gugurnya Orient tidak otomatis pasangan bupati dan wakil bupati yang mendapat perolehan suara terbanyak kedua menang. Mahkamah Konstitusi menjelaskan KPU harus menggelar pilkada ulang dengan diikuti dua calon dalam batas waktu yang ditetapkan. Tetapi dalam putusan akhir orient riwu keru terbukti sebagai warga indonesia asli yang pernah bekerja di amerika serikat.
\end{abstract}

Kata kunci : Diskualifikasi, terbukti, putusan. 
A. Latar Belakang

Mahkamah konstitusi memutuskan mendiskualifikasi bupati Sabu Raijua terpilih ORIENT RIWU KORE.dari hasil pengumpulan data dan keterangan dari berbagai pihak, Orient masih berstatus sebagai warga negara Amerika Serikat (AS).

Hal itu diputuskan dalam pembacaan sidang putusan perkara 135/ PHP.BUP-XIX/2021 yang dilayangkan oleh pasangan calon nomor urut tiga Taken Irianto Radja Pono dan Herman Hegi Rdja Haba dalam pilkada Sabu Raijua.

Berdasarkan bukti yang dikumpulkan, Mahkamah Konstitusi mengatakan status Orient sejak 2007 adalah warga negara Amerika Serikat (AS). Hal itu dibuktikan dengan kepemilikan paspor Amerika Serikat.

Jika mengacu pada undangundang Nomor 12 tahun 2006, indonesia menganut asas kewarganegaraan tunggal. Sehingga saat Orient mempunyai paspor Amerika Serikat, saat itu secara otomatis status Warga Negara Indonesia (WNI) tidak berlaku.

Selain itu mengacu pada pasal 7 ayat (1) UU Nomor 10 tahun 2016 terkait persyaratan pencalonan bupati dan wakil bupati mengharuskan berstatus Warga Negara Indonesia (WNI). Sehingga pencalonan Orient tidak dapat diterima. ${ }^{1}$ Mahkamah Konstitusi menganggap Orient tidak jujur

\footnotetext{
${ }^{1}$ Anwar usman (ketua Mahkamah Konstitusi)15/4/2021
}

terhadap status

kewarganegaraannya selama ini.

Dengan gugurnya Orient, Mahkamah Konstitusi mengatakan pendampingnya, Thobias Uly juga ikut gugur.pasangan calon bupati dan wakil bupati adalah satu kesatuan

Namun demikian, Mahkamah Konstitusi mengatakan gugurnya Orient tidak otomatis pasangan bupati dan wakil bupati yang mendapat perolehan suara terbanyak kedua menang. Mahkamah Konstitusi menjelaskan KPU harus menggelar pilkada ulang dengan diikuti dua calon dalam batas waktu yang ditetapkan.

Diketahui KPU Sabu Raijua menetapkan pasangan Orient Riwu kore dan Thobias Uly sebagai bupati dan wakil bupati terpilih pada Desember 2020 lalu. Mereka meraih 21.395 suara atau 28,3 persen suara sah.

Orient seharusnya dilantik pada 17 Februari 2021 lalu. Namun, kementerian dalam negeri terus menunda sampai dua kalikarena masih mendalami kasus kewarganegaraan Orient. Dalam amar putusan yang dibacakan ketua mahkamah konstitusi Anwar Usman, mahkamah konstitusi membatalkan empat keputusan KPU kabupaten sabu rajiua (Termohon). Pertama Keputusan nomor 342/HK-Kpt/5320/KPUKab/XII/2020 Tentang penetapan rekapitulasi hasil penghitungan suara pemilihan bupati dan wakil bupati sabu rajiua tahun 2020 bertanggal 16 desember 2020 . 
Kedua mahkamah konstitusi membatalkan keputusan KPU kabupaten sabu rajiua nomor 152/HK.03.1-Kpt/5320//KPUKab/IX/2020 Tentang penepatan pasangan calon bupati dan wakil bupati yang memenuhi syarat sebagai peserta pemilihan bupati dan wakil bupati sabu raijua tahun 2020 bertanggal 23 september 2020. Ketiga mahkamah konstitusi batalkan keputusan KPU kabupaten sabu raijua nomor 153/HK.03.1-Kpt/5320/KPU$\mathrm{Kab} / \mathrm{IX} / 2020$ tentang penepatan nomor urut 2 (Orient patriot riwu kore dan thobias Uly). Keempat, mahkamah konstitusi membatalkan keputusan KPU kabupaten sabu raijua nomor 25/HK/03.1Kpt/5420/KPU$\mathrm{Kab} / 2021$ tentang penepatan pasangan calon bupati dan wakil bupati terpilih dalam pemilihan bupati dan wakil bupati sabu raijua tahun 2020 bertanggal 23 januari $2021^{2}$. Hal terpenting, mahkamah konstitusi pun memerintahkan termohon untuk melaksanakan pemungutan suara ulang pemilhan bupati dan wakil bupati kabupaten sabu raijua tahun 2020 dengan diikuti dua pasangan calon nomor urut 1 Nikdemus N. Rihi heke dan yohanis Uly kale serta pasangan calon nomor urut 3 taken radja pono dan herman hegi radja haba. Mahkamah konstitusi juga memerintahkan pemungutan suara ulang tersebut waktu 60 hari kerja sejak putusan diucapkan. Dalam pertimbangannya yang dibacakan hakim konstitusi sadi isra, MK ( Mahkamah Konstitusi)

${ }^{2}$ Aida Mardatillah HukumOnline.com (16 April 2021)

Menemukan fakta hukum bahwa orient patriot riwu kore mempunyai dua paspor. Dua paspor tersebut, yaitu paspor Ri (Republik Indonesia) nomor X746666 yang berlaku 1 april 2019 sampai dengan april 2024 sesuai keteragan ditjen imigrasi kemenkumham dan paspor amerika serikat nomor 574900485 yang berlaku 10 juli 2017 sampai dengan 9juli 2027, menurut MK (Mahkamah Konstitusi) kepemilikan paspor amerika serikat atau paspor negara asing lainnya, jika merujuk pasal 23 huruf $h$ jo huruf a dan huruf b UU No. 12 tahun 2006 tentang kewarganegaraan RI (Republik Indonesia),membawa konsekuensi bahwa orient patriot riwu kore seharusnya secara serta merta warga negara indonesia tanpa harus melalui mekanisme administratif pelepasan kewarganegaraan. 
B. HASIL PENELITIAN DAN PEMBAHASAN

1. HASIL PENELITIAN.

Putusan Mahkamah konstitusi

PUTUSAN NOMOR 134/PHP.BUP-XIX/2021 DEMI KEADILAN BERDASARKAN KETUHANAN YANG MAHA ESA MAHKAMAH KONSTITUSI REPUBLIK INDONESIA,

[1.1] Yang mengadili pada tingkat pertama dan terakhir, menjatuhkan putusan dalam perkara Perselisihan Hasil Pemilihan Bupati dan Wakil Bupati Sabu Raijua, Provinsi Nusa Tenggara Timur, Tahun 2020, yang diajukan oleh:

1. Nama : Herman Lawe Hiku

2. Pekerjaan : Wiraswasta

3. Alamat: Menia, RT 18 RW 009 Desa Menia, Kecamatan Sabu Barat, Kabupaten Sabu Raijua.

Dalam hal ini bertindak sebagai perseorangan Warga Negara Indonesia dan terdaftar dalam Daftar Pemilih Tetap dalam Pemilihan Bupati dan Wakil Bupati Sabu Raijua Tahun 2020,

Selanjutnya disebut sebagai-Pemohon I 2.

1. Nama : Marthen Radja

2. Pekerjaan : Petani

3. Alamat : Lobohode, RT 005/RW 003 Desa Lobohede Kecamatan Hawu Mehara, Kabupaten Sabu Raijua.

Dalam hal ini bertindak sebagai perseorangan Warga Negara Indonesia yang terdaftar dalam Daftar Pemilih Tetap dalam Pemilihan Bupati dan Wakil Bupati Sabu Raijua Tahun 2020, selanjutnya disebut sebagai---

Pemohon II 3.

1. Nama : Yanuarse Bawa Lomi

2. Jabatan : Ketua Aliansi Masyarakat Peduli Demokrasi Sabu Raijua (AMAPEDO)

3. Alamat : Eilode RT 012/RW 006 Dusun 3 Desa Eilode, Kecamatan Sabu Tengah, Kabupaten Sabu Raijua.

Dalam hal ini bertindak untuk dan atas nama Aliansi Masyarakat Peduli 
Demokrasi Sabu Raijua (AMAPEDO), selanjutnya disebut sebagai Pemohon III.

Berdasarkan Surat Kuasa Khusus Nomor 01/SKK/MK/I/2021, bertanggal 13 Februari 2021, memberi kuasa kepada Yafet Yosafet Wilben Rissy, S.H., M.Si., LLM., PhD dan Bram Perwita Anggadatama, S.H., advokat/kuasa hukum pada Kantor Hukum Yafet Rissy and Partners Law Firm, yang beralamat di Perum Satya Asri I/6, Blotongan, Salatiga, Jawa Tengah, Indonesia, baik sendiri-sendiri atau bersamasama bertindak untuk dan atas nama Pemberi Kuasa; Selanjutnya disebut sebagai para Pemohon;

Terhadap: Komisi Pemilihan Umum Kabupaten Sabu Raijua, beralamat di Jalan Eltari KM. 03, Kelurahan Mebba, Kecamatan Sabu Barat, Kabupaten Sabu Raijua. Berdasarkan Surat Kuasa Khusus Nomor 101/SKK/LO-JV\&P/III/2021 bertanggal 6 Maret 2021 memberi kuasa kepada Josua Victor, S.H., Alfonsus Hilarius Ase, S.H., M.Hum, Walidi, S.H., Sudwijayanti, S.H., M.H.,

Akmal Hidayat, S.H., S.H.I., M.H., Faisal Wahyudi Wahid Putra, S.H., M.H., M.Kn., Tondi Madingin Akbar Niwal Situmeang, S.H., Rintisman Harta Wijaya, S.H., Bernard M. Saragih, S.H., Suci Azkiya, S.H., dan Muhammad Fadli Amrullah, S.H., para advokat dan asisten advokat pada kantor Law Office | JOSUA I VICTOR \& Partners beralamat di Graha Hanurata 5th Floor Suite 509-510, Jln. Kebon Sirih Kav. 67-69 Jakarta, baik secara sendiri-sendiri maupun bersamasama bertindak untuk dan atas nama Pemberi Kuasa; Selanjutnya disebut sebagai ---Termohon.

Berkenaan dengan permohonan di atas, berikut ini:

1. (1). Nama : Drs. Orient P. Riwu Kore

2. Alamat: Kelurahan Nunbaun Sabu, RT/RW 003/001, Kecamatan Alak, Kota Kupang, Provinsi Nusa Tenggara Timur.

3. (2). Nama : Ir. Thobias Uly, M.Si

4. Alamat : Lingkungan Kampung Baru RT 024 RW 009, Kelurahan Penfui, Kecamatan Maulafa, Kota Kupang.

Pasangan Calon Bupati dan Wakil Bupati dalam Pemilihan Bupati dan Wakil Bupati Sabu Raijua Tahun 2020, Nomor Urut 2;

Berdasarkan Surat Kuasa Khusus bertanggal 28 Februari 2021, memberi kuasa kepada Dr. Yanuar P. Wasesa, S.H., M.Si., M.H., Dr. Erna Ratnaningsih, S.H., LL.M., Abadi Hutagalung, S.H, Paskaria Tombi, S.H., M.H., M. Nuzul Wibawa, S.Ag., M.H., M. Ihsan Tanjung, S.H., M.H., M.Si., Yodben Silitonga, S.H., Benny Hutabarat, S.H., Heri Perdana Tarigan, S.H., Mulyadi Marks Phillian, S.H., M.Si., Aries Surya, S.H., Johanes L. Tobing, S.H., M.H., Elya Daylon Sitanggang, S.H., M.H., Wiradarma Harefa, S.H., M.H., Martina, S.H., M.H., Dr. Sophar Maru Hutagalung, S.H., M.H., P.S. Jemmy Mokolengkang, S.H., Army Mulyanto, S.H., Rikardus Sihura, S.H., Fajri Syafi'i, S.H., Roy Jansen Siagian, S.H., Arie Achmad, S.H., Samuel David, S.H., Ryan Kurniawan, S.H., M.Hum., Michael Kanta Germansa, S.H., M.H., Roy Valiant Sembiring, S.H., Karto Nainggolan, S.H., Efri Donal Silaen, S.H., I Made Ananta Jaya Artha, S.H., Andi Hamonangan Limbong, S.H., dan Devyani Petricia, S.H., kesemuanya advokat atau konsultan hukum pada "BADAN BANTUAN HUKUM DAN ADVOKASI RAKYAT (BBHAR) PUSAT PDI PERJUANGAN, yang beralamat di Jalan Pegangsaan Barat Nomor 30, Menteng, 
Jakarta Pusat, baik sendiri-sendiri atau bersama-sama bertindak untuk dan atas nama Pemberi Kuasa; Selanjutnya disebut sebagai ----Pihak Terkait.

[1.2] Membaca dan mendengar permohonan para Pemohon; Mendengar keterangan para Pemohon; Membaca dan mendengar Jawaban Termohon; Membaca dan mendengar Keterangan Pihak Terkait; Membaca dan mendengar Keterangan Badan Pengawas Pemilihan Umum (Bawaslu) Kabupaten Sabu Raijua; Memeriksa bukti-bukti para Pemohon, Termohon, Pihak Terkait dan Bawaslu Kabupaten Sabu Raijua; Mendengar dan membaca keterangan ahli para Pemohon serta ahli dan saksi Pihak Terkait; Mendengar keterangan Kedutaan Besar Republik Indonesia di Washington DC; Mendengar keterangan Konsulat Jenderal Republik Indonesia di Los Angeles. Mendengar keterangan Direktorat Jenderal Imigrasi Kementerian Hukum dan Hak Asasi Manusia; Mendengar keterangan Kantor Wilayah Imigrasi Provinsi Nusa Tenggara Timur; Mendengar keterangan Kantor Imigrasi Kelas I Kota Kupang; Mendengar keterangan Direktorat Jenderal Kependudukan dan Pencatatan Sipil Kementerian Dalam Negeri; Mendengar keterangan Dinas Kependudukan dan Pencatatan Sipil Kota Kupang.

\section{Duduk perkara}

Menimbang bahwa para Pemohon telah mengajukan permohonan dengan surat permohonannya bertanggal 15 Februari 2021 yang diajukan ke Kepaniteraan Mahkamah Konstitusi (selanjutnya disebut Kepaniteran Mahkamah) pada tanggal 16 Februari 2021, pukul 11.47 WIB, berdasarkan Akta Pengajuan Permohonan Pemohon Nomor 138/PAN.MK/AP3/02/2020, yang telah diperbaiki dan diterima di Kepaniteraan Mahkamah pada tanggal 18 Februari 2021 dan dicatat dalam Buku Registrasi Perkara Konstitusi dengan Perkara Nomor 134/PHP.BUPXIX/2021 pada tanggal 26 Februari 2021 yang pada pokoknya mengemukakan halhal sebagai berikut:

1. KEWENANGAN MAHKAMAH KONSTITUSI.

a. Bahwa Pasal 24C ayat (1) (2) (3) UUD 1945 menyatakan:

(1) Kekuasaan Kehakiman merupakan kekuasaan yang merdeka untuk menyelenggarakan peradilan guna menegakkan hukum dan keadilan.

(2) Kekuasaan kehakiman dilakukan oleh sebuah Mahkamah Agung dan badan peradilan yang berada di bawahnya dalam lingkungan peradilan umum, lingkungan peradilan agama, lingkungan peradilan militer, lingkungan peradilan tata usaha negara, dan oleh sebuah Mahkamah Konstitusi.

(3) Badan-badan lain yang fungsinya berkaitan dengan kekuasaan kehakiman diatur dalam undang-undang.

b. Bahwa Pasal 10 ayat (1) huruf a sampai dengan d Undang-Undang Nomor 24 Tahun 2003 tentang Mahkamah Konstitusi mengatur mengenai kewenangan Mahkamah Konstitusi (constitutionally entrusted powers) adalah:

a. Menguji undang-undang terhadap UUD 1945. 
b. Memutus sengketa kewenangan antar lembaga negara yang kewenangannya diberikan oleh UUD 1945.

c. Memutus pembubaran partai politik.

d. Memutus perselisihan tentang hasil pemilu.

c. Bahwa pemilihan Bupati dan Wakil Bupati merupakan bagian dari pemilihan umum sehingga Mahkamah Konstitusi berwewenang mengadili permohonan para Pemohon.

d. Bahwa berdasarkan Pasal 157 ayat (3) UU Nomor 10 Tahun 2016 tentang perkara perselisihan penetapan perolehan suara hasil tahap akhir pemilihan diperiksa dan diadili oleh Mahkamah Konstitusi sampai dibentuknya badan peradilan khusus;

e. Bahwa Pasal 2 Peraturan Mahkamah Konstitusi Nomor 6 Tahun 2020 tentang Tata Beracara Dalam Perkara Perselisihan Hasil Pemilihan Gubernur, Bupati, Dan Walikota menyatakan bahwa objek sengketa dalam perselisihan hasil pemilihan adalah "keputusan termohon mengenai penetapan perolehan suara hasil pemilihan yang signifikan dan dapat mempengaruhi penetapan calon terpilih".

f. Bahwa sekalipun demikian patutlah kiranya dipahami bahwa "keputusan Termohon mengenai penetapan perolehan suara hasil pemilihan yang signifikan dan dapat mempengaruhi penetapan calon terpilih" di atas yang dalam perkara a quo adalah Keputusan Komisi Pemilihan Umum Kabupaten Sabu Raijua Nomor 342/HK.03.1-Kpt/5320/KPU-Kab/XII/2020 tentang Penetapan Rekapitulasi Hasil Perhitungan Suara dan Penetapan Hasil Pemilihan Bupati dan Wakil Bupati Sabu Raijua Tahun 2020, tanggal 16 Desember 2020 (Bukti P-1), yang kemudian diikuti oleh Keputusan Komisi Pemilihan Umum Kabupaten Sabu Raijua Nomor 25/HK/03.1Kpt/5420/KPUKab/2021 tentang Penetapan Pasangan Calon Bupati dan Wakil Bupati Terpilih dalam Pemilihan Bupati dan Wakil Bupati Sabu Raijua Tahun 2020,

\section{KEDUDUKAN HUKUM (LEGAL STANDING) PEMOHON}

a. Bahwa sejauh ini, sesuai ketentuan Pasal 2 Peraturan Mahkamah Konstitusi Nomor 6 Tahun 2020 tentang Tata Beracara Dalam Perkara Perselisihan Hasil Pemilihan Gubernur, Bupati, Dan Walikota, obyek sengketa yang menjadi kewenangan Mahkamah Konstitusi adalah "keputusan termohon mengenai penetapan perolehan suara hasil pemilihan yang signifikan dan dapat mempengaruhi penetapan calon terpilih".

b. Bahwa berdasarkan Pasal 4 ayat (1) Peraturan Mahkamah Konstitusi Nomor 6 Tahun 2020 tentang Tata Cara Beracara Dalam Perkara Perselihan Hasil Pemilihan Gubernur, Bupati, dan Walikota (Peraturan Mahkamah Konstitusi 6 
2020) yang menyatakan:

(1) Pemohon dalam Perkara Perselisihan Hasil Pemilihan adalah:

a. pasangan calon Gubernur dan Wakil Gubernur;

b. pasangan calon Bupati dan Wakil Bupati;

c. pasangan calon Walikota dan Wakil Walikota; atau

d. pemantau pemilihan dalam hal hanya terdapat satu pasangan calon.

c. Bahwa dengan demikian, sejauh obyek yang disengketakan adalah "keputusan termohon mengenai penetapan perolehan suara hasil pemilihan yang signifikan dan dapat mempengaruhi penetapan calon terpilih" maka yang memiliki legal standing ialah pasangan calon bupati NAMUN legal standing inipun telah gugur karena telah melampaui waktu yang diberikan oleh Peraturan MK Nomor 6 Tahun 2020.

d. Bahwa sekalipun demikian, Para pemohon sebagai warga negara dan aliansi dari warga negara (AMAPEDO), memiliki legal standing untuk mengajukan permohonan ini karena prinsip luhur yang dikandung dalam konstitusi untuk melindungi segenap warga negara Indonesia yang diciderai hak konstitusonalnya antara lain hak untuk memilih dan dipilih secara demokratis, jujur dan adil, melalui pemilu yang bermartabat.

e. Bahwa Permohonan para Pemohon juga didorong oleh kenyataan bahwa kini terjadi kekosongan hukum (recthsvacuum) sehingga diperlukan terobosan progresif oleh Mahkamah Konstitusi. Tanggung jawab konstitusonal para Pemohon sebagai warga negara ini didorong oleh Pemikiran Dworkin mengenai 'hard cases', yakni kasus-kasus yang sulit dan unik, yang tidak diatur dalam ketentuan peraturan perundangan-undangan yang berlaku dan tidak memiliki preseden sebelumnya diberikan ruang bagi warga negara manapun untuk (Ronald Dworkin, 1975, 'Hard Cases', Harvard Law Review, 88 (6) p.1057, 1059 dan Ronald Dworkin, 1967, 'Model of Rules', University of Chicago Law Review, 35 (14), p.23).

f. Bahwa Permohonan para Pemohon juga didasarkan Precedent tersohor yang diakui sebagai salah satu keputusan terbaik Mahkamah Agung Amerika Serikat yang terbaik sepanjang sejarah Amerika yang dimotori oleh Hakim Ketua (Chief Justice) John Marshal dalam kasus Marbury v. Madison (1803) di mana dalam perkara ini Mahkamah Agung Amerika memeriksa perkara ini berdasarkan prinsip-prinsip yang terkandung dalam konstitusi bukan undangundang (karena ketiadaan undang-undang) (Davison M. Douglas, 2003, "The Rhetorical Uses of Marbury v. Madison: The Emergence of a "Great Case'", Wake Forrest Law Review, Vol. 38, p. 375).

g. Bahwa perihal dan pokok permohon para Pemohon tidaklah mempersoalkan perselisihan suara semata-mata sebagaimana diijinkan Oleh UU No 10 Tahun 2016 dan PMK Nomor 6 Tahun 2020, tetapi lebih dari pada itu permohonan 
ini penetapan pasangan calon, mempersoalkan penetapan nomor urut pasangan calon, penetapan rekapitulasi dan hasil pemilihan, dan juga penetapan pasangan calon terpilih dalam pemilihan Bupati dan Wakil Bupati Sabu Raijua Tahun 2020, yang merupakan resultante dari sebuah proses yang cacat formil, melawan konstitusi, hukum dan moral.

h. Bahwa sebagaimana telah diuraikan di bagian I. Permohonan a quo tentang Kewenangan Mahkamah Konsitusi, terdapat fakta yang baru diketahui belakangan hari setelah proses penetapan pasangan calon, pemilihan, rekapitulasi hasil suara dan penetapan pasangan calon Bupati dan Wakil Bupati Terpilih yakni berupa adanya kewarganegaraan Amerika Calon Bupati dari Pasion Nomor Urut 2, sudah tidak dapat lagi diselesaikan melalui proses gugatan TUN Pemilihan sebagaimana diatur dalam Peraturan Mahkamah Agung RI Nomor 11 Tahun 2016 tentang Tata Cara Penyelesaian Sengketa Tata Usaha Negara Pemilihan Dan Sengketa Pelanggaran Administrasi Pemilihan karena telah lewat (daluwarsa) waktunya.

i. Bahwa sebagaimana telah diuraikan di bagian I. Permohonan Pemohon tentang Kewenangan Mahkamah Konsitusi, terdapat fakta yang baru diketahui belakangan hari setelah proses penetapan pasangan calon, pemilihan, rekapitulasi hasil suara dan penetapan pasangan calon Bupati dan Wakil Bupati Terpilih yakni berupa adanya kewarganegaraan Amerika Calon Bupati dari Pasion Nomor Urut 2, sudah tidak bisa juga diselesaikan oleh Bawaslu berdasarkan Pasal 142 jo. Pasal 143 ayat (2) Undang-Undang Nomor 10 Tahun 2016 tentang Perubahan Kedua Atas Undang-Undang Nomor 1 Tahun 2015 tentang Penetapan Peraturan Pemerintah Pengganti Undang-Undang Nomor 1 Tahun 2014 Tentang Pemilihan Gubernur, Bupati, Dan Walikota Menjadi Undang-Undang karena telah lewat (daluwarsa) waktunya.

j. Bahwa Undang-Undang Nomor 10 Tahun 2016 tentang Perubahan Kedua Atas Undang-Undang Nomor 1 Tahun 2015 tentang Penetapan Peraturan Pemerintah Pengganti Undang-Undang Nomor 1 Tahun 2014 tentang Pemilihan Gubernur, Bupati, Dan Walikota Menjadi Undang-Undang juga tidak mengatur mengenai diskualifikasi pasangan calon bupati dan wakil bupati yang terpilih tetapi belakangan diketahui pencalonannya cacat formil.

k. Bahwa dalam konteks ini, masalahnya ialah para Pemohon tidak dapat mentolerir sebuah situasi hukum yang memungkinkan warga negara asing diperbolehkan mengikuti pemilihan Bupati dan kemudian ditetapkan sebagai Bupati Terpilih

I. Bahwa menurut para Pemohon, persoalan yang terjadi di Sabu Raijua di mana Bupati terpilihnya adalah warga negara asing yakni warga negara Amerika Serikat telah secara nyata dan terang benderang melanggar UUD 1945, hukum dan moral, sehingga para Pemohon memiliki tanggungjawab konstitusional untuk mencegah keberlanjutan pelanggaran yang serius ini sehingga oleh karenanya para Pemohon berpendapat memiliki legal standing 
untuk mengajukan permohonan ini ke Mahkamah Konstitusi yang terhormat ini.

m. Bahwa berdasarkan uraian-uraian di atas juga menjadi sejauh ini tidak terdapat norma (hukum) dan presenden yang bisa dipakai Hakim untuk memeriksa dan mengadili permohonan para pemohon sehingga Mahkamah Konstitusi berdasarkan kewenangan yang dijaminkan oleh UUD 1945, Undang-Undang Nomor 48 Tahun 2009 tentang Kekuasaan Kehakiman dan Nomor 7 Tahun 2020 tentang Perubahan Ketiga Atas Undang-Undang Nomor 24 Tahun 2003 tentang Mahkamah Konstitusi, memiliki kewajiban konstitusional, hukum dan moral untuk memeriksa dan mengadili Permohonan Pemohon.

Bahwa berdasarkan uraian tersebut di atas menurut para Pemohon, para Pemohon memiliki kedudukan hukum untuk mengajukan:

i. Permohonan agar Mahkamah Konstitusi sebagai the positive legislator melakukan penemuan hukum untuk mengatasi kebuntuan dan kekosongan hukum sehubungan dengan status kewarganegaraan asing (Amerika Serikat) Bupati terpilih Sabu Raijua, Nusa Tenggara Timur.

ii. Permohonan Pembatalan Keputusan Komisi Pemilihan Umum Kabupaten Sabu Raijua Nomor 153/HK.03.1-Kpt/5320/Kpu-kab/IX/2020 tentang Penetapan Nomor Urut dan Daftar Pasangan Calon Peserta Pemilihan Bupati dan Wakil Bupati Sabu Raijua Tahun 2020, beserta Lampirannya, tanggal 24 September 2020.

iii. Pembatalan Keputusan Komisi Pemilihan Umum Kabupaten Sabu Raijua Nomor 152/HK.03.1-Kpt/5320/KPU-Kab/IX/2020 tentang Penetapan Pasangan Calon Peserta Pemilihan Bupati dan Wakil Bupati Sabu Raijua Tahun 2020, tanggal 23 September 2020

iv. Permohonan Pembatalan Keputusan Komisi Pemilihan Umum Kabupaten Sabu Raijua Nomor 342/HK.03.1-Kpt/5320/KPU-Kab/XII/2020 bertanggal 16 Desember 2020 tentang Penetapan Rekapitulasi Hasil Perhitungan Suara dan Penetapan Hasil Pemilihan Bupati dan Wakil Bupati Sabu Raijua Tahun 2020, tanggal 16 Desember 2020.

v. Permohonan Pembatalan Keputusan Komisi Pemilihan Umum Kabupaten Sabu Raijua Nomor 25/HK/03.1-Kpt/5420/KPU-Kab/2021 tentang Penetapan Pasangan Calon Bupati dan Wakil Bupati Terpilih dalam Pemilihan Bupati dan dan Wakil Bupati Sabu Raijua Tahun 2020, tanggal 23 Januari 2020.

\section{TENGGANG WAKTU PENGAJUAN PERMOHONAN}

1.Bahwa sejauh ini, jika yang dipersoalkan adalah semata-mata terkait dengan penetapan KPU(D) Sabu Raijua terkait dengan perselisihan hasil suara maka berdasarkan Pasal 157 ayat (5) Undang-Undang Nomor 10 Tahun 2016 juncto Pasal 7 ayat (2) Peraturan Mahkamah Konstitusi Nomor 6 Tahun 2020, maka permohonan tersebut hanya dapat diajukan paling lama 3 (tiga) hari kerja terhitung sejak diumumkan penetapan perolehan suara hasil pemilihan oleh Termohon.

2.Bahwa dalam Permohonan ini, para Pemohon tidak mempersoalkan perselisihan suara semata-mata tetapi mempersoalkan isu konstitusionalitas dan hukum dan moral dari sejumlah Keputusan KPU Sabu Raijua dalam rangakaian tahapan pemilihan yang cacat formil, bersifat melawan konstitusi, hukum dan moral.

3.Bahwa patutlah dipahami bahwa dua Keputusan Termohon yakni: i. Keputusan Komisi Pemilihan Umum Kabupaten Sabu Raijua Nomor 153/HK.03.1Kpt/5320/Kpu-kab/IX/2020 tentang Penetapan Nomor Urut dan Daftar Pasangan Calon 
Peserta Pemilihan Bupati dan Wakil Bupati Sabu Raijua Tahun 2020 , beserta Lampirannya, tanggal 24 September 2020;

ii. Keputusan Komisi Pemilihan Umum Kabupaten Sabu Raijua Nomor 152/HK.03.1-

Kpt/5320/KPU-Kab/IX/2020 tentang Penetapan Pasangan Calon Peserta Pemilihan Bupati dan Wakil Bupati Sabu Raijua Tahun 2020, tanggal 23 September 2020.

Telah melegalkan Pasangan Calon Nomor Urut 2 dalam pemilihan Bupati dan Wakil Bupati Sabu Raijua untuk selanjutnya mengikuti pemilihan yang hasil pemilihannya telah ditetapkan dan dan kemudian ditetapkan menjadi Pasangan Calon Bupati dan Wakil Bupati Terpilih Sabu Raijua melalui keputusan Termohon yakni:

i. $\quad$ Keputusan Komisi Pemilihan Umum Kabupaten Sabu Raijua Nomor 25/HK .03.1Kpt/5320/KPU-Kab/1/2021 tentang Penetapan Rekapitulasi Hasil Perhitungan Suara dan Penetapan Hasil Pemilihan Bupati dan Wakil Bupati Sabu Raijua 2020 dalam pemilihan calon Bupati dan Wakil Bupati Kabupaten Sabu Raijua Tahun 2020 tertanggal 23 Januari 2021

ii. Keputusan Komisi Pemilihan Umum Kabupaten Sabu Raijua Nomor 25/HK/03.1Kpt/5420/KPU-Kab/2021 tentang Penetapan Pasangan Calon Bupati dan Wakil Bupati Terpilih dalam Pemilihan Bupati dan dan Wakil Bupati Sabu Raijua Tahun 2020, tanggal 23 Januari 2020.

4.Bahwa oleh karenanya Keputusan Termohon di atas haruslah dinyatakan cacat formil, bersifat melawan konstitusi, hukum dan moral sehingga selayaknya dibatalkan demi martabat konstitusi, hukum dan moral.

5.Bahwa oleh karenanya, didorong oleh semangat untuk menghormati dan menegakkan UUD 1945 (konstitusi), hukum dan moral, termasuk memperjuangkan hak-hak konstitusional para Pemohon dan setelah mempertimbangkan urgensi dan kegentingan dari perkara a quo bagi tegaknya konstitusi, hukum dan moral, para Pemohon memutuskan untuk mendaftarkan perkara a quo pada kesempatan pertama.

6.Bahwa berdasarkan uraian tersebut di atas , menurut Pemohon, permohonan Pemohon yang diajukan ke Mahkamah Konstitusi demi tegaknya konsitusi, keadilan dan kebenaran materil (substantive) sepatutnya dipertimbangkan dalam tenggang waktu pengajuan permohonan dan untuk selanjutnya diperiksa, diadili dan diputuskan oleh Mahkamah Konstitusi yang terhormat ini.

\section{POKOK PERMOHONAN}

1. Bahwa pemilihan Bupati dan Wakil Bupati Sabu Raijua, Nusa Tenggara Timur (NTT) Tahun 2020 telah dilakukan dalam beberapa tahap penyelenggaraan antara lain (Vide) Pasal 5 ayat (3) Undang-Undang Nomor 10 Tahun 2016 tentang Perubahan Kedua Atas UndangUndang Nomor 1 Tahun2015 tentang Penetapan Peraturan Pemerintah Pengganti UndangUndang Nomor 1 Tahun 2014 tentang Pemilihan Gubernur, Bupati, Dan Walikota Menjadi Undang-Undang):

a. Tahapan Penetapan Pasangan Calon Peserta Pemilihan Bupati dan Wakil Bupati Sabu Raijua Tahun 2020, tanggal 23 Januari 2020 (lihat Bukti P-3) yang dikuti dengan

b. Penetapan Nomor Urut dan Daftar Pasangan Calon Peserta Pemilihan Bupati dan Wakil Bupati Sabu Raijua Tahun 2020, tanggal 24 September 2020 (lihat Bukti P-3) yang diikuti dengan

c. Pemilihan suara dan Penetapan Rekapitulasi Hasil Perhitungan Suara dan Penetapan Hasil Pemilihan Bupati dan Wakil Bupati Sabu Raijua Tahun 2020, tanggal 16 Desember 2020 (lihat Bukti P-1)

d. Penetapan Pasangan Calon Bupati dan Wakil Bupati Terpilih dalam Pemilihan Bupati dan dan Wakil Bupati Sabu Raijua Tahun 2020, tanggal 23 Desember 2020 (lihat Bukti P-2).

2. Bahwa komplikasi konstitusional, hukum dan moral seriusnya muncul ketika diketahui bahwa Calon Bupati dari Pasangan Calon (Paslon) Nomor Urut 2 atas nama Orient 
Patriot Riwu Kore dinyatakan secara resmi oleh Kedutaan Besar Amerika Serikat di Jakarta tanggal 1 Februari 2020, bahwa yang bersangkutan adalah memegang warga negara Amerika Serikat.

3. Bahwa Calon Bupati dari Pasangan Calon (Pasion) Nomor Urut 2 atas nama Orient Patriot Riwu Kore telah mengakui bahwa dia memiliki Passport Amerika Serikat dan berkewarganegaraan Amerika Serikat.

4. Bahwa oleh karena Calon Bupati dari Pasangan Calon (Paslon) Nomor Urut 2 atas nama Orient Patriot Riwu Kore memegang kewarganegaraan Amerika Serikat maka dengan sendirinya Status WNI-nya otomatis hilang sesuai dengan ketentuan dalam Pasal 23 Huruf a UU Nomor 12 Tahun 2006 tentang Kewarganegaraan Republik Indonesia khususnya jo. Pasal 31 ayat (1) huruf a Peraturan Pemerintah Republik Indonesia Nomor 2 Tahun 2007 tentang Tata Cara Memperoleh, Kehilangan, Pembatalan, Dan Memperoleh Kembali Kewarganegaraan Republik Indonesia yang menyatakan bahwa "Warga Negara Indonesia kehilangan kewarganegaraannya jika yang bersangkutan: memperoleh kewarganegaraan lain atas kemauannya sendiri";

5. Bahwa Rumusan Pasal 23 huruf a UU Nomor 12 Tahun 2006 tentang Kewarganegaraan Republik Indonesia di atas sesungguhnya mengandung pengakuan bahwa Indonesia tidak menganut asas dual citizenship (kewargangeraan ganda) sehingga sekali lagi bagi WNI yang telah menerima kewarganegraan Amerika dengan sendirinya tidak lagi menyandang status WNInya atau gugur secara otomatis status WNI-nya.

6. Bahwa fakta di atas menunjukan adanya pelanggaran serius atas konstitusi (Baca UUD 1945) yang dilakukan oleh Calon Bupati dari Pasangan Calon (Paslon) Nomor Urut 2 atas nama Orient Patriot Riwu Kore dalam pemilihan Bupati dan Wakil Bupati Sabu Raijua 2020 dan dilakukan oleh Termohon karena Warga negara Amerika Serikat tidak memiliki hak yang setara dengan WNI dalam urusan pemerintahan sebagaimana dimaksud dalam Pasal 27 ayat (1) UUD 1945 bahwa: "Segala warga Negara bersamaan kedudukannya di dalam hukum dan pemerintahan dan wajib menjunjung hukum dan pemerintahan itu dengan tidak ada kecualinya."

7. Bahwa fakta status warga negara Amerika yang dipegang oleh Orient Patriot Riwu Kore yang ditetapkan oleh Termohon sebagai sebagai calon Bupati dari Paslon Nomor 2 dalam pemilihan Bupati dan Wakil Bupati Sabu Raijua 2020 juga menciderai Pasal 28 ayat (1) UUD 1945 menentukan bahwa: (1) Setiap orang berhak atas pengakuan, jaminan, perlindungan, dan kepastian hukum yang adil serta perlakuan yang sama di hadapan hukum. dan ayat (3) "setiap warga negara berhak memperoleh kesempatan yang sama dalam pemerintahan".

8. Bahwa dalam konteks ini Calon Bupati dari Pasangan Calon (Paslon) No urut 2 atas nama Orient Patriot Riwu Kore dan Penyelenggara Pemilihan yakni KPUD Sabu Raijua telah melanggar hak konstitusional para Pemohon dan merampas secara melawan hukum peluang WNI lainnya, untuk terlibat dalam pemerintahan sebagai calon Bupati dan telah memperlakukan WNI lainnya secara tidak adil dalam konteks pemilihan Bupati dan Wakil Bupati Sabu Raijua 2020.

9. Bahwa fakta status warga negara Amerika Serikat yang dipegang oleh Calon Bupati dari Pasangan Calon (Paslon) Nomor Urut 2 atas nama Orient Patriot Riwu Kore dan fakta Termohon telah meloloskan yang bersangkutan sebagai calon Bupati dari Paslon Nomor 2 dalam pemilihan Bupati dan Wakil Bupati Sabu Raijua 2020 juga melanggar hak dasar WNI untuk dipilih dan memilih secara demokratis sebagaimana diatur dalam Pasal 43 UU Nomor 39 Tahun 1999 tentang Hak Asasi Manusia yang menyatakan bahwa "Setiap warga negara berhak untuk dipilih dan memilih dalam pemilihan umum berdasarkan persamaan hak melalui pemungutan suara yang langsung, umum, bebas, rahasia, jujur, dan adil sesuai dengan ketentuan peraturan perundang-undangan."

10. Bahwa keputusan-keputusan Termohon yang harusnya dinyatakan batal demi hukum adalah:

a. Keputusan Komisi Pemilihan Umum Kabupaten Sabu Raijua Nomor 152/HK.03.1Kpt/5320/KPU-Kab/IX/2020 tentang Penetapan Pasangan Calon Peserta Pemilihan Bupati 
dan Wakil Bupati Sabu Raijua Tahun 2020, tanggal 23 September 2020;

b. Keputusan Komisi Pemilihan Umum Kabupaten Sabu Raijua Nomor 153/HK.03.1-

Kpt/5320/Kpu-kab/IX/2020 tentang Penetapan Nomor Urut dan Daftar Pasangan Calon

Peserta Pemilihan Bupati dan Wakil Bupati Sabu Raijua Tahun 2020, beserta Lampirannya, tanggal 24 September 2020;

c. Pembatalan Keputusan Komisi Pemilihan Umum Kabupaten Sabu Raijua Nomor

342/HK.03.1-Kpt/5320/KPU-Kab/XII/2020 tentang Penetapan Rekapitulasi Hasil Perhitungan

Suara dan Penetapan Hasil Pemilihan Bupati dan Wakil Bupati Sabu Raijua Tahun 2020 ,

tanggal 16 Desember 2020;

d. Pembatalan Keputusan Komisi Pemilihan Umum Kabupaten Sabu Raijua Nomor

25/HK/03.1-Kpt/5420/KPU-Kab/2021 tentang Penetapan Pasangan Calon Bupati dan Wakil

Bupati Terpilih dalam Pemilihan Bupati dan Wakil Bupati Sabu Raijua Tahun 2020, tanggal 23 Januari 2020.

\section{PETITUM}

Berdasarkan seluruh uraian sebagaimana tersebut di atas, para Pemohon memohon kepada Mahkamah Konstitusi untuk menjatuhkan putusan sebagai berikut:

Dalam Putusan Sela:

1. Menyatakan bahwa Mahkamah Konstitusi berwewenang memeriksa, mengadili dan memutuskan permohonan para Pemohon.

2. Memutuskan menunda pelantikan Pasangan Calon Bupati dan Wakil Bupati Terpilih Sabu Raijua dalam Pemilihan Bupati dan Wakil Bupati Sabu Raijua Tahun 2020 hingga adanya Putusan final Mahkamah Konstitusi.

ATAU

3. Memutuskan membatalkan pelantikan (jika telah dilantik) Pasangan Calon Bupati dan Wakil Bupati Terpilih Sabu Raijua dalam Pemilihan Bupati dan Wakil Bupati Sabu Raijua Tahun 2020

Dalam Pokok Perkara

1. Mahkamah Konstitusi berdasarkan fungsinya sebagai the positive legislator dapat melakukan penemuan hukum ketika terdapat kasus-kasus keras (sulit) atau hard cases yang tidak diatur dalam undang-undang dan tidak memiliki yurisprudensi (preseden).

2. Menyatakan tidak sah dan tidak berdasar hukum dan bersifat melawain hukum dan oleh karenanya membatalkan Keputusan Komisi Pemilihan Umum Kabupaten Sabu Raijua Nomor 152/HK.03.1-Kpt/5320/KPU-Kab/IX/2020 tentang Penetapan Pasangan Calon Peserta Pemilihan Bupati dan Wakil Bupati Sabu Raijua Tahun 2020, 23 September 2020.

3. Menyatakan tidak sah dan tidak berdasar hukum dan bersifat melawan dan oleh karenanya membatalkan Keputusan Komisi Pemilihan Umum Kabupaten Sabu Raijua Nomor 153/HK.03.1-Kpt/5320/Kpu-kab/IX/2020 tentang Penetapan Nomor Urut dan Daftar Pasangan Calon Peserta Pemilihan Bupati dan Wakil Bupati Sabu Raijua Tahun 2020, beserta Lampirannya, tanggal 24 September 2020.

4. Menyatakan tidak sah dan tidak berdasar hukum dan bersifat melawan dan karenanya membatalkan Keputusan Komisi Pemilihan Umum Kabupaten Sabu Raijua Nomor 342/HK .03.1-Kpt/5320/KPU-Kab/XII/2020 tentang Penetapan Rekapitulasi Hasil Perhitungan Suara dan Penetapan Hasil Pemilihan Bupati dan Wakil Bupati Sabu Raijua Tahun 2020, tanggal 16 Desember 2020.

5. Menyatakan tidak sah dan tidak berdasar hukum dan bersifat melawan Keputusan Komisi Pemilihan Umum Kabupaten Sabu Raijua Nomor 25/HK/03.1-Kpt/5420/KPUKab/2021 tentang Penetapan Pasangan Calon Bupati dan Wakil Bupati Terpilih dalam Pemilihan Bupati dan dan Wakil Bupati Sabu Raijua Tahun 2020, tanggal 23 Januari 2020

6. Mendiskualifikasi Pasangan Calon Nomor Urut 2 atas nama Orient Patriot Riwu Kore dan Ir. Thobias Uly, M.Si. dalam Pemilihan Umum Bupati dan Wakil Bupati Sabu Raijua Tahun 2020. 
7. Memerintahkan agar Komisi Pemilihan Umum Kabupaten Sabu Raijua Menetapkan peraih suara terbanyak kedua yakni Pasangan Calon Nomor Urut 1 yakni Drs. NIKODEMUS NITHANEL RIHI HEKE,M.Si dan YOHANIS ULY KALE, A.Md sebagai Bupati Terpilih dan Wakil Bupati Terpilih Sabu Raijua dalam Pemilihan Bupati dan Wakil Bupati Sabu Raijua Tahun 2020.

ATAU

8. Menetapkan agar Komisi Pemilihan Umum Kabupaten Sabu Raijua melakukan Pemungutan Suara Ulang pemilihan Bupati dan Wakil Bupati Sabu Raijua Tahun 2020 dalam waktu selambat-lambatnya 2 (dua) bulan sejak putusan Mahkamah Konstitusi ditetapkan DENGAN HANYA MELIBATKAN PASANGAN CALON NOMOR 1 yakni Drs. NIKODEMUS NITHANEL RIHI HEKE,M.Si dan YOHANIS ULY KALE, A.Md DAN PASANGAN NOMOR URUT 3 yakni IR. TAKEM IRIANTO RADJA PONO, MSI DAN HERMAN HEGI RADJA HABA.

9. Memerintahkan kepada Komisi Pemilihan Umum Kabupaten Sabu Raijua untuk melaksanakan putusan ini.

ATAU

Apabila Mahkamah Konstitusi berpendapat lain, mohon putusan yang seadil-adilnya (ex aequo et bono).

[2.2] Menimbang bahwa untuk membuktikan dalil permohonannya, para Pemohon telah mengajukan bukti surat/tulisan yang diberi tanda bukti P-1 sampai dengan bukti P-13, sebagai berikut:

1.Bukti P-1:

Fotokopi Keputusan KPU Kabupaten Sabu Raijua Nomor 342/HK.03.1-Kpt/5320/Kpu$\mathrm{Kab} / \mathrm{XII} / 2020$ tentang Penetapan Rekapitulasi Hasil Perhitungan Suara dan Penetapan Hasil Pemilihan Bupati dan Wakil Bupati Sabu Raijua Tahun 2020, tanggal 16 Desember 2020; 2.Bukti P-2:

Fotokopi Keputusan Komisi Pemilihan Umum Kabupaten Sabu Raijua Nomor 25/HK/03.1Kpt/5320/KPU-Kab/I/2021 Tentang Penetapan Pasangan Calon Bupati dan Wakil Bupati Terpilih dalam Pemilihan Bupati dan dan Wakil Bupati Sabu Raijua Tahun 2020, tanggal 23 Januari 2020;

3.Bukti P-3:

Fotokopi Keputusan Komisi Pemilihan Umum Kabupaten Sabu Raijua Nomor 152/HK.03.1Kpt/5320/KPU-Kab/IX/ 2020 tentang Penetapan Pasangan Calon Bupati dan Wakil Bupati Yang Memenuhi Syarat Sebagai Peserta Pemilihan Bupati dan Wakil Bupati Sabu Raijua Tahun 2020, tanggal 23 September 2020;

4.Bukti P-4:

Fotokopi Keputusan Komisi Pemilihan Umum Kabupaten Sabu Raijua Nomor 153/HK.03.1Kpt/5320/Kpu-Kab/IX/ 2020 tentang Penetapan Nomor Urut dan Daftar Pasangan Calon Peserta Pemilihan Bupati dan Wakil Bupati Sabu Raijua Tahun 2020, beserta Lampirannya, tanggal 24 September 2020;

5.Bukti P-5:

Fotokopi Surat Keterangan dari Kedutaan Besar Amerika Serikat di Jakarta, tanggal 1

Februari 2021;

6.Bukti P-6:

Fotokopi Surat yang dilayangkan Bawaslu Kabupaten Sabu Raijua kepada Kedutaan Amerika Serikat Nomor 136/K. Bawaslu-SR/HK.00.021/IX/2020 tanggal 15 September 2020 perihal Permohonan Informasi Data Kewarganegaraan Amerika Serikat Orient Patriot Riwu kore 7.Bukti P-7:

Fotokopi Artikel kompas.com memberitakan pengakuan Orient Patriot Riwu Kore, bahwa dia memilik paspor Amerika Serikat

8.Bukti P-8:

Fotokopi Artikel Detik.com yang memberitakan bahwa pengakuan Orient Patriot Riwu Kore 
adalah warga negara Amerika;

9.Bukti P-9:

Fotokopi postingan pemilik akun dengan nama FB Yonathan Gah, yang merupakan salah

satu Pendukung Orient Patriot Riwu Kore ,memberikan postingan mengenai Curriculum Vitae

Calon Bupati;

10.Bukti P-10:

Fotokopi Surat Keterangan yang dikeluarkan Kepala Suku Dinas Kependudukan dan

Pencatatan Sipil Jakarta Selatan Kastpel/Pengadministrasian Adminduk (Jamilah);

11.Bukti P-11: Fotokopi KTP yang diterbitkan dari Kota Jakarta Utara atas nama Drs. Orient

P Riwu Kore dengan NIK 3172020710640008 tertanggal 20 Maret 2019;

12.Bukti P-12:

Fotokopi KTP yang diterbitkan dari Kota Jakarta Utara atas nama Drs. Orient P Riwu Kore dengan NIK 3172020710640008 tertanggal 02 Oktober 2019;

Bukti P-12.1:

Fotokopi KTP atas nama Drs. ORIENT P.RIWU KORE dengan NIK 3172020710640008

tertanggal 09 Agustus 2019, yang beralamatkan di Kel. Nunbaun Sabu, Kec Alak Kota

Kupang

Bukti P-12.2:

Fotokopi NPWP 93.680.859.1-048.000 ORIENT P RIWU KORE NIK

3172020710640008 KEL. NUNBAUN SABU NUNBAUN SABU ALAK KPP PRATAMA

KUPANG terdaftar 9 Desember 2019;

13.Bukti P-13:

Fotokopi SK PWNI dari Jakarta Selatan.

[2.3] Menimbang bahwa terhadap permohonan para Pemohon, Termohon telah menyerahkan jawaban tertulis bertanggal 12 Maret 2021 dan menyampaikan jawaban dalam persidangan Mahkamah pada tanggal 15 Maret 2021, yang pada pokoknya sebagai berikut:

I. DALAM EKSEPSI

1. KEWENANGAN MAHKAMAH KONSTITUSI

Bahwa Mahkamah Konstitusi tidak berwenang memeriksa, mengadili, dan memutus perkara yang diajukan oleh HERMAN LAWE HIKU, MARTHEN RADJA selaku perorangan Warga Negara Indonesia dan YANUARSE BAWA LOMI untuk dan atas nama Aliansi Masyarakat Peduli Demokrasi Sabu Raijua (AMAPEDO) dengan alasan:

1.1. Bahwa berdasarkan ketentuan Pasal 10 ayat (1) huruf $a$, huruf $b$, huruf $c$ dan huruf $d$ Undang-Undang Nomor 24 Tahun 2003 tentang Mahkamah Konstitusi, mengatur mengenai kewenangan Mahkamah Konstitusi, yakni berwenang mengadili pada tingkat pertama dan terakhir yang putusannya bersifat final untuk:

a. Menguji undang-undang terhadap Undang-Undang Dasar Negara Republik Indonesia Tahun 1945.

b. Memutus sengketa kewenangan lembaga negara yang kewenangannya diberikan oleh Undang-Undang Dasar Negara Republik Indonesia Tahun 1945.

c. Memutus pembubaran partai politik.

d. Memutus perselisihan tentang hasil pemilihan umum.

1.2. Bahwa sejak diundangkannya Undang-Undang Nomor 10 Tahun 2016 tentang

Perubahan Kedua Atas Undang-Undang Nomor 1 Tahun 2015 tentang Peraturan Pemerintah

Pengganti Undang-Undang Nomor 1 Tahun 2014 tentang Pemilihan Gubernur, Bupati, dan

Walikota Menjadi Undang-Undang, telah dikualifikasikan bentuk pelanggaran, sengketa dan perselisihan beserta dengan lembaga yang memiliki kewenangan untuk menyelesaikannya yaitu:

\begin{tabular}{|l|l|}
\hline \multicolumn{1}{|c|}{ BENTUK PELANGGARAN } & \multicolumn{1}{c|}{ KOMPETENSI LEMBAGA } \\
\hline Pelanggaran Administrasi Pemilihan yang & 1. Bawaslu \\
Bersifat Terstruktur, Sistematis dan masif. & 2. Mahkamah Agung \\
\hline Pelanggaran Kode Etik & DKPP \\
\hline
\end{tabular}




\begin{tabular}{|l|l|}
\hline $\begin{array}{l}\text { Pelanggaran Administrasi dan Sengketa } \\
\text { Pemilihan }\end{array}$ & Bawaslu \\
\hline Pelanggaran Pidana & $\begin{array}{l}\text { Sentra Gakumdu, } \\
\text { Pengadilan Negeri dan } \\
\text { Pengadilan Tinggi }\end{array}$ \\
\hline Sengketa Tata Usaha Negara Pemilihan & $\begin{array}{l}\text { Bawaslu, Pengadilan Tata Usaha } \\
\text { Negara dan Mahkamah Agung }\end{array}$ \\
\hline Perselisihan Hasil Pemilihan & Mahkamah Konstitusi \\
\hline
\end{tabular}

Bahwa berdasarkan ketentuan tersebut, terhadap pelanggaran, sengketa atau perselisihan hasil yang berkaitan dengan penyelenggaraan Pemilihan Gubernur, Bupati dan Walikota terdapat lembaga-lembaga yang memiliki kewenangan untuk menyelesaikan permasalahan yang terjadi di setiap tahapan pemilihan.

1.3. Bahwa ketentuan Pasal 156 ayat (1) dan ayat (2) Undang-Undang Nomor 10 Tahun 2016 menyatakan:

1) Perselisihan hasil pemilihan merupakan perselisihan antara KPU Provinsi dan/atau KPU Kabupaten/Kota dan peserta pemilihan mengenai penetapan perolehan suara hasil pemilihan.

2) Perselisihan penetapan perolehan suara hasil pemilihan sebagaimana dimaksud pada ayat (1) adalah perselisihan penetapan perolehan suara yang signifikan dan dapat mempengaruhi penetapan calon terpilih.

1.4. Bahwa ketentuan Pasal 157 ayat (3) Undang-Undang Nomor 10 Tahun 2016 menyatakan bahwa perkara perselisihan penetapan perolehan suara tahap akhir hasil pemilihan diperiksa dan diadili oleh Mahkamah Konstitusi sampai dibentuknya badan peradilan khusus.

1.5. Bahwa ketentuan Pasal 2 Peraturan Mahkamah Konstitusi Nomor 6 Tahun 2020 menyatakan bahwa: "Objek dalam perkara perselisihan hasil pemilihan adalah Keputusan Termohon mengenai penetapan perolehan suara hasil pemilihan yang signifikan dan dapat memengaruhi penetapan calon terpilih"

Bahwa ketentuan tersebut di atas mengandung makna yang jelas dan tegas (expressis verbis), maka dapat ditarik 2 (dua) unsur yang harus terpenuhi dan menjadi pengertian perselisihan hasil pemilihan yang menjadi kewenangan Mahkamah Konstitusi, yaitu: pemilihan

a. Perselisihan antara KPU Provinsi dan/atau KPU Kabupaten/Kota dan peserta

b. Objek sengketanya adalah penetapan perolehan suara hasil pemilihan;

\section{PEMOHON TIDAK MEMILIKI KEDUDUKAN HUKUM}

2.1. Bahwa ketentuan Pasal 156 ayat (1) Undang-Undang Nomor 10 Tahun 2016 menetapkan bahwa: "Perselisihan hasil pemilihan merupakan perselisihan antara KPU Provinsi dan/atau KPU Kabupaten/Kota dan peserta pemilihan mengenai penetapan perolehan suara hasil pemilihan";

2.2. Bahwa ketentuan Pasal 4 ayat (1) Peraturan Mahkamah Konstitusi Nomor 6 Tahun 2020 tentang Tata Beracara Dalam Perkara Perselisihan Hasil Pemilihan Gubernur, Bupati dan Walikota, menetapkan: "Pemohon dalam perkara hasil perselisihan adalah:

a. Pasangan calon Gubernur dan Wakil Gubernur,

b. Pasangan calon Bupati dan Wakil Bupati,

c. pasangan calon Walikota dan Wakil Walikota, atau

d. Pemantau pemilihan dalam hal hanya terdapat satu pasangan calon";

2.3. Bahwa Pemohon dalam bagian uraian dalil kedudukan hukum (legal standing) huruf $c$ mendalilkan sebagai berikut "Bahwa dengan demikian sejauh objek yang disengketakan adalah keputusan Termohon mengenai penetapan perolehan suara yang signifikan dan 
dapat mempengaruhi penetapan calon terpilih maka yang memiliki legal standing adalah pasangan calon Bupati namun legal standing inipun telah gugur karena telah melampaui waktu yang diberikan oleh Peraturan Mahkamah Konstitusi Nomor 6 Tahun 2020";

2.4. Bahwa dengan adanya ketentuan mengenai legal standing, berarti tidak semua orang atau pihak mempunyai hak mengajukan permohonan ke Mahkamah Konstitusi. Hanya mereka yang benar-benar mempunyai kepentingan hukum saja yang boleh menjadi pemohon, namun Pemohon menciptakan aturan baru dengan membuat pemaknaan sendiri/tafsiran sendiri tentang legal standing Pemohon dalam permohonan Pemohon, padahal ketentuan Pasal 4 ayat (1) Peraturan Mahkamah Konstitusi Nomor 6 Tahun 2020 tentang Tata Beracara dalam Perkara Perselisihan Hasil Pemilihan Gubernur, Bupati dan Walikota dengan sangat terang dan jelas telah menentukan bahwa "Pemohon dalam perkara hasil perselisihan adalah:
a. Pasangan calon Gubernur dan Wakil Gubernur,
b. Pasangan calon Bupati dan Wakil Bupati,
c. Pasangan calon Walikota dan Wakil Walikota, atau
d. Pemantau pemilihan dalam hal hanya terdapat satu pasangan calon";

2.5. Bahwa Pemohon HERMAN LAWE HIKU, tempat dan tanggal lahir: Mania 06 Maret 1963, agama: Kristen, alamat: Mania, RT.18 RW.009, Desa Mania, Kecamatan Sabu Barat, Kabupaten Sabu Raijua, Provinsi Nusa Tenggara Timur, pekerjaan: Wiraswasta, NIK: 5320010603630003 dalam hal ini bertindak sebagai orang perorangan Warga Negara Indonesia dan bukan pasangan calon Bupati dan Wakil Bupati Sabu Raijua;

2.6. Bahwa Pemohon MARTHEN RADJA, tempat dan tanggal lahir: Labohede 12 Desember 1961, agama: Kristen, alamat: RT.005/RW.004, Desa Labohede, Kecamatan Hawumehara, Kabupaten Sabu Raijua, Provinsi Nusa Tenggara Timur, pekerjaan: Petani, NIK: 5320011212610002 dalam hal ini bertindak sebagai orang perorangan Warga Negara Indonesia bukan pasangan calon Bupati dan Wakil Bupati Sabu Raijua;
2.7. Bahwa Pemohon YANUARSE BAWA LOMI, Jabatan Ketua Aliansi Masyarakat Peduli Demokrasi Sabu Raijua (AMAPEDO) Alamat: RT.012/RW.004, Dusun 3, Desa Eilode, Kecamatan Sabu Tengah, Kabupaten Sabu Raijua, Provinsi Nusa Tenggara Timur, pekerjaan: Petani, NIK: 5320010101710001 dalam hal ini bertindak untuk dan atas nama Aliansi Masyarakat Peduli Demokrasi Sabu Raijua (AMAPEDO) adalah Aliansi yang belum melaporkan/ mendaftarkan serta tidak terdaftar keberadaannya di Kantor Kesatuan Bangsa dan Politik Kabupaten Sabu Raijua sebagaimana Surat Keterangan yang dikeluarkan oleh Sekretariat Daerah Pemerintah Kabupaten Sabu Raijua Nomor 224/27/Kesbang-SR/III/2021, tertanggal 10 Maret 2021 (Bukti T-1) dan bukan pula sebagai Lembaga Pemantau Pemilu dalam pemilihan Bupati dan Wakil Bupati Sabu Raijua Tahun 2020;

\subsection{Bahwa sesuai Berita Acara rapat pleno penetapan Pasangan Calon Bupati dan Wakil} Bupati Sabu Raijua pada tertanggal 23 September 2020 (Bukti T-2), yang dituangkan dalam Keputusan KPU Kabupaten Sabu Raijua Nomor 152/HK.03.1-Kpt/5320/KPU-kab/IX/2020 tentang Penetapan Pasangan Calon Bupati dan Wakil Bupati yang memenuhi syarat sebagai peserta pemilihan Bupati dan Wakil Bupati Sabu Raijua Tahun 2020, tertanggal 23

September 2020 (Bukti T-3), Pasangan Calon dalam pemilihan Bupati dan Wakil Bupati Sabu Raijua Tahun 2020 adalah pasangan calon Drs. Nikodemus N. Rihi Heke, M.Si dan Yohanis Uly Kale, A.Md, pasangan calon Drs. Orient P. Riwu Kore dan Ir. Thobias Uly, M.Si dan pasangan calon Ir. Takem Irianto Radja Pono, M.Si dan Ir. Herman Hegi Radja Haba;

2.9. Bahwa berdasarkan ketentuan Pasal 156 ayat (1) Undang-Undang Nomor 10 Tahun 2016, ketentuan Pasal 4 ayat (1) Peraturan Mahkamah Konstitusi Nomor 6 Tahun 2020 huruf b dan huruf d, serta Keputusan KPU Kabupaten Sabu Raijua Nomor 152/HK.03.1-Kpt/ 
5320/KPU-kab/IX/2020, tanggal 23 September 2020, maka Herman Lawe Hiku, Marthen Radja perorangan warga negara Indonesia dan Yanuarse Bawa Lomi untuk dan atas nama Aliansi Masyarakat Peduli Demokrasi Sabu Raijua (AMAPEDO) adalah tidak memiliki kedudukan hukum (legal standing) untuk mengajukan permohonan kepada Mahkamah Konstitusi.

Berdasarkan Berita Acara dan Sertifikat Rekapitulasi Hasil Penghitungan Suara dari setiap kecamatan di tingkat Kabupaten/Kota dalam pemilihan Bupati dan Wakil Bupati tahun 2020 Kabupaten Sabu Raijua Termohon/KPU Kabupaten Sabu Raijua menetapkan Keputusan KPU Kabupaten Sabu Raijua Nomor 342/HK.03.1-Kpt/5320/KPU-Kab/XII/2020 tentang Penetapan Rekapitulasi Hasil Penghitungan Suara Pemilihan Bupati dan Wakil Bupati Sabu Raijua tahun 2020, tertanggal 16 Desember 2020 (Bukti T-42) dengan rincian perolehan suara sebagai berikut:

\begin{tabular}{|c|c|c|c|}
\hline NO & NAMA PASLON & $\begin{array}{c}\text { PEROLEHAN SUARA } \\
\text { PASLON }\end{array}$ & PERSENTASI \\
\hline 1. & $\begin{array}{c}\text { Nikodemus N Rihi Heke, M.Si } \\
\& \\
\text { Yohanis Uly Kale }\end{array}$ & 13.313 suara & $30,10 \%$ \\
\hline 2. & $\begin{array}{c}\text { Drs. Orient Riwu Kore, M.Si } \\
\text { \& } \\
\text { Thobias Uly, M.Si }\end{array}$ & 21.363 suara & $48,30 \%$ \\
\hline 3. & $\begin{array}{c}\text { Ir. Taken Radja Pono, M.Si } \\
\& \\
\text { Herman Hegi Radja Haba M.Si }\end{array}$ & 9.557 suara & $21,60 \%$ \\
\hline & Total suara sah & 44.233 & $100 \%$ \\
\hline
\end{tabular}

Bahwa dalam rapat pleno terbuka rekapitulasi hasil perolehan suara pasangan calon dalam Pemilihan Bupati dan Wakil Bupati Sabu Raijua Tahun 2020 yang di hadiri oleh Bawaslu Kabupaten Sabu Raijua, Pasangan Calon Nomor Urut 2 Partai Politik Pengusul serta undangan lainnya sebagaimana daftar hadir peserta rapat pleno (Bukti T-43), tidak terdapat keberatan tentang hasil rekapitulasi perolehan suara pasangan calon baik dari Bawaslu Kabupaten Sabu Raijua ataupun pasangan calon sebagaimana dalam Model D-KWK Kejadian Khusus Kabupaten Tidak terdapat Catatan Keberatan, tertanggal 16 Desember 2020 (Bukti T-44);

\section{DALAM POKOK PERMOHONAN}

1. Bahwa pokok dan inti permohonan para Pemohon dalam perkara ini adalah sebagai berikut:

A. Keputusan dan atau penetapan Termohon in casu Komisi pemilihan umum kabupaten Sabu raijua dalam penyelenggaraan Pemilihan Bupati Kabupaten Sabu Raijua sebagaimana tertuang dalam: 
1. Keputusan Komisi Pemilihan Umum Kabupaten Sabu Raijua Nomor 152/HK.03.1Kpt/5320/KPU-Kab/IX/2020, tanggal 23 September 2020 tentang Penetapan Pasangan Calon Peserta Pemilihan Bupati dan Wakil Bupati Yang Memenuhi Syarat Sebagai Peserta Pemilihan Bupati dan Wakil Bupati Sabu Raijua Tahun 2020.

2. Keputusan Komisi Pemilihan Umum Kabupaten Sabu Raijua Nomor 153/HK.03.1Kpt/5320/KPU-Kab/IX/2020 tanggal 24 September 2020 tentang Penetapan Nomor Urut dan Daftar Pasangan Calon Peserta Pemilihan Bupati dan Wakil Bupati Sabu Raijua Tahun 2020.

3. Keputusan Komisi Pemilihan Umum Kabupaten Sabu Raijua Nomor 342/HK.03.1Kpt/5320/KPU-Kab/XII/2020, tanggal 16 Desember 2020 tentang Penetapan Rekapitulasi Hasil penghitungan Suara dan Penetapan Hasil Pemilihan Bupati dan Wakil Bupati Sabu Raijua Tahun 2020.

4. Keputusan Komisi Pemilihan Umum Kabupaten Sabu Raijua Nomor 25/HK.03.1Kpt/5320/KPU-Kab/l/2021, tanggal 23 Januari 2021 tentang Penetapan Pasangan Calon Bupati dan Wakil Bupati Terpilih Dalam Pemilihan Bupati dan Wakil Bupati Sabu Raijua Tahun 2020.

Inti dari seluruh persoalan yang diajukan oleh Pemohon adalah Apakah pada saat pencalonan, Orient $\mathrm{P}$ Riwu Kore adalah berkewarganegaraan Amerika sehingga yang bersangkutan tidak memenuhi persyaratan untuk menjadi Pasangan Calon sebagaimana diatur di dalam Pasal 7 UU Nomor 10 Tahun 2016 jo. Pasal 1 angka 18 Peraturan KPU Nomor 1 Tahun 2020 ?

untuk menjawab hal tersebut maka Pihak Terkait akan terlebih dahulu menjelaskan secara terperinci sebagai berikut :

A. ORIENT P RIWU KORE (PIHAK TERKAIT) ADALAH BERKEWARGANEGARAAN INDONESIA SEJAK LAHIR DAN TIDAK PERNAH TERPUTUS.

Bahwa Orient P Riwu Kore adalah Putra Asli Indonesia yang berasal dari Kupang, NTT. Lahir di Nunbaun Sabu Kupang pada 7 Oktober 1965 dari pasangan Drs. Agustinus David Riwu Kore dan Ema Mariance Koroh Dimu. Orient bersekolah di SD Inpress Nunbun Sabu Kupang (1971-1977], SMP 1 Kupang (1977-1980), SMA 1 Kupang (1980-1983), dan Universitas Nusa Cendana Kupang jurusan pendidikan administrasi niaga (1983-1987).

B. ORIENT P RIWU KORE TIDAK PERNAH MENGAJUKAN PERMOHONAN PELEPASAN KEWARGANEGARAAN INDONESIA DAN TIDAK PERNAH ADA DOKUMEN RESMI PENCABUTAN KEWARGANEGARAAN INDONESIA DARI KEMENTERIAN TERKAIT. Berdasarkan ketentuan tersebut, dikarenakan pada tahap pencalonan yaitu di bulan September 2020 tidak ada laporan dan proses klarifikasi serta keputusan menteri sehubungan dengan pencabutan kewarganegaraan Indonesia milik Orient P Riwu Kore. Oleh karenanya, Orient $\mathrm{P}$ Riwu Kore adalah warga negara Indonesia yang status kewarganegaraannya wajib dilindungi oleh Hukum Indonesia.

C. FAKTA PEROLEHAN KEWARGANEGARAAN AMERIKA ORIENT P RIWU KORE ADALAH MERUPAKAN PEMENUHAN PERSYARATAN ADMINISTRASI DALAM PEKERJAAN DAN BUKAN BERDASARKAN KEINGINANNYA. Orient P Riwu Kore (Pihak Terkait) adalah WNI yang bekerja di Amerika Serikat sejak tahun 1997 dan menikah dengan warga negara Amerika Serikat di tahun 2000 dan berdasarkan pernikahan, Orient mendapatkan Green Card sejak 14 Agustus 2000.Pada tahun 2006, Orient P Riwu Kore mulai bekerja sebagai Technician pada General Dynamics NASSCO, sebuah perusahaan yang bergerak di bidang pembuatan kapal tempur untuk angkatan laut Amerika Serikat dan kapal minyak (Nasco.com). Oleh karena sifat pekerjaan NASSCO tersebut, maka setiap karyawan yang akan dipekerjakannya, wajib untuk memiliki kewarganegaraan Amerika [U.S citizenship is required]. 
D. FAKTA PERIHAL PASPOR AMERIKA (US CITIZENSHIP) YANG DIMILIKI OLEH ORIENT P RIWU KORE TELAH DIAJUKAN PEMBATALAN/ PENCABUTAN/PELEPASANNYA MELALUI KEDUTAAN AMERIKA SERIKAT DI JAKARTA PADA TANGGAL 5 BULAN AGUSTUS TAHUN 2020 (SEBELUM PENDAFTARAN SEBAGAI PASANGAN CALON) Bahwa atas permintaan orang tua, Orient P Riwu Kore kembali ke Indonesia pada tahun 2019 untuk mengikuti kontestasi Pilkada Kabupaten Sabu Raijua. Bahwa pada bulan Agustus 2020, Orient P Riwu Kore mengajukan permohonan pelepasan kewarganegaraan dengan melakukan pengisian Form "Request for Determination of Possible Loss of United States Citizenship" melalui Kedutaan Amerika Serikat di Indonesia. Namun yang sangat disayangkan adalah karena kelalaian dari Kedutaan Besar Amerika Serikat, sehingga permohonan pelepasan kewarganegaraan tersebut saat itu tidak ditindaklanjuti dengan alasan covid.

E. FAKTA ADANYA SURAT DARI KEDUTAAN BESAR AMERIKA SERIKAT YANG MENERANGKAN BAHWA ORIENT P RIWU KORE SEBAGAI PEMEGANG PASPOR AMERIKA BUKANLAH ALAT BUKTI YANG DAPAT DIJADIKAN ACUAN PERIHAL KEWARGANEGARAAN GANDA Bahwa Status WNI seseorang tidak ditentukan semata-mata berdasarkan surat keterangan kedutaan negara asing bahwa yang bersangkutan memiliki paspor asing, melainkan berdasarkan pemenuhan ketentuan peraturan perundang-undangan. Bahwa korespondensi e-mail yang dilakukan Orient P Kore Riwu pada tanggal 5 Agustus 2020 perihal permohonan Pelepasan Kewarganegaraan Amerika melalui "Request for Determination of Possible Loss of United States Citizenship" yang tidak ditindaklanjuti oleh Pihak Kedutaan Amerika Serikat dan kemudian pada tanggal 1 Februari 2021 justru Kedutaan Amerika Serikat di Jakarta mengeluarkan surat keterangan perihal Orient P Riwu Kore adalah pemegang paspor Amerika adalah hal yang tidak bersesuaian dan tidak dapat dibenarkan secara hukum.

\section{KESIMPULAN}

Berdasarkan elaborasi fakta dan aturan hukum Indonesia, hukum Amerika Serikat di atas maka dapat dipastikan bahwa:

1. Bahwa Orient Patriot Riwu Kore telah memenuhi persyaratan sebagai calon sebagaimana diatur di dalam Pasal 7 UU Pilkada jo. Pasal 1 angka 18 Per KPU Nomor 1 Tahun 2020 karena yang bersangkutan memiliki dan menyerahkan KTP yang aktif pada waktu mendaftar sebagai pasangan calon;

2. Bahwa UU Kewarganegaraan Indonesia Nomor 12 Tahun 2006 jo. PP Nomor 2 Tahun 2007 mengatur perihal peristiwa yang dapat menyebabkan seseorang dapat kehilangan kewarganegaraannya. Namun peristiwa tersebut wajib diinisiasi dalam bentuk laporan, dilakukan klarifikasi serta adanya produk tertulis berupa keputusan dari Kementerian terkait yang menyatakan secara tertulis perihal kehilangan/pencabutan/pelepasan status kewarganegaraan. Pada saat pendaftaran sebagai pasangan calon, tidak ada laporan atau pun keputusan Menteri terkait yang menyatakan pencabutan Kewarganegaraan Indonesia dari Orient P Riwu Kore;

3. Bahwa fakta terdapat pengajuan pemohonan resmi pencabutan status kewarganegaraan Amerika yang bersangkutan kepada pemerintah Amerika Serikat pada bulan Agustus 2020 sebagai syarat pelepasan kewarganegaraan Amerika menurut hukum Amerika sebagaimana diatur Section 349 INA (8U.S.C. 1481) letter (a) point 5 maka Orient patriot Riwu Kore demi hukum telah hilang kewarganegaraan Amerikanya dan tetap sebagai warga negara Indonesia, atau berkewarganegaraan tunggal sebagai WNI;

Berdasarkan uraian sebagaimana tersebut di atas, Pihak Terkait memohon kepada Mahkamah Kontitusi untuk menjatuhkan putusan sebagai berikut:

- DALAM EKSEPSI

Mengabulkan eksepsi Pihak Terkait untuk seluruhnya 


\section{- DALAM POKOK PERMOHONAN}

1. Menolak Permohonan Pemohon untuk seluruhnya;

2. Menyatakan benar, sah dan tetap berlaku:

1. Keputusan Komisi Pemilihan Umum Kabupaten Sabu Raijua Nomor 152/HK.03.1Kpt/5320/KPU-Kab/IX/2020, tanggal 23 September 2020 tentang Penetapan Pasangan Calon Peserta Pemilihan Bupati dan Wakil Bupati Yang Memenuhi Syarat Sebagai Peserta Pemilihan Bupati dan Wakil Bupati Sabu Raijua Tahun 2020;

2. Keputusan Komisi Pemilihan Umum Kabupaten Sabu Raijua Nomor 153/HK.03.1Kpt/5320/KPU-Kab/IX/2020 tanggal 24 September 2020 tentang Penetapan Nomor Urut dan Daftar Pasangan Calon Peserta Pemilihan Bupati dan Wakil Bupati Sabu Raijua Tahun 2020;

3. Keputusan Komisi Pemilihan Umum Kabupaten Sabu Raijua Nomor 342/HK.03.1Kpt/5320/KPU-Kab/XII/2020, tanggal 16 Desember 2020 tentang Penetapan Rekapitulasi Hasil penghitungan Suara dan Penetapan Hasil Pemilihan Bupati dan Wakil Bupati Sabu Raijua Tahun 2020;

4. Keputusan Komisi Pemilihan Umum Kabupaten Sabu Raijua Nomor 25/HK.03.1Kpt/5320/KPU-Kab/I/2021, tanggal 23 Januari 2021 tentang Penetapan Pasangan Calon Bupati dan Wakil Bupati Terpilih Dalam Pemilihan Bupati dan Wakil Bupati Sabu Raijua Tahun 2020.

\section{PEMBAHASAN}

Perkara ini, secara khusus menjadi perkara yang sangat menarik perhatian, bukan saja karena segi karakteristik dasar permohonan yang diajukan Pemohon, menyangkut adanya persoalan dwi-kewarganegaran yang muncul kepermukaan, yang boleh jadi tidak disadari sejak awal baik penyelenggara maupun Pasangan Calon Peserta Pemilukada lainnya, bahkan oleh Pihak Terkait, berkenaan dengan prosedur dan proses penyelesaian pelepasan kewarganegaraan asing yang pernah diperolehnya, sehingga menimbulkan persoalan yang harus terlebih dahulu diputus oleh $\mathrm{MK}$, berkenaan dengan objectum litis kewenangan MK, yang telah melalui rangkaian keputusan TUN Penyelenggara dalam bentuk Keputusan yang berantai (kettingsbesckkingen), dan pokok permohonan sendiri yang menyatakan bahwa Pemohon tidak mempersoalkan proses penyelenggaraan Pemilukada dan hasil penetapan perolehan suara, melainkan mempersoalkan adanya pelanggaran terhadap asas mandiri, jujur dan adil dalam penyelenggaraan Pemilukada
Kabupaten Sabu Raijua Tahun 2020, karena kekuarang cermatan Termohon, tetapi dalam perbaikan permohonan kemudian menyatakan dalam perihal: "Permohonan Pembatalan Keputusan Komisi Pemilihan Umum Kabupaten Sabu Raijua Nomor 342/HK.03.1-Kpt/5320/KPU -Kab/2020 Tentang Penetapan Rekapitulasi Perhitungan Suara Pemilihan Bupati dan Wakil Bupati Terpilih Dalam Pemilihan Bupati dan Wakil Bupati Sabu Raijua Tahun 2020 tertanggal 16 Desember2020, dan mengajukan permohonan perihal Pembatalan Hasil Pemilihan Calon Bupati dan Wakil Bupati Kabupaten Sabu Raijua, berdasarkan Keputusan Komisi Pemilihan Umum Kabupaten Sabu Raijua Nomor 342/HK.03.1-KPT/5320/KPU$\mathrm{Kab} / \mathrm{XII} / 2020$ tentang Penetapan Hasil Penghitungan Suara Pemilihan Bupati dan Wakil Bupati Sabu Raijua Tahun 2020 tertanggal 16 Desember 2020."

\footnotetext{
${ }^{3}$ Ahli Dr. Maruarar Siahaan, S.H.
} 
PERTIMBANGAN HUKUM

Kewenangan Mahkamah

Dalam Eksepsi

[3.1] Menimbang bahwa sebelum

Mahkamah mempertimbangkan lebih jauh

kewenangan Mahkamah dalam mengadili

permohonan a quo, penting bagi

Mahkamah untuk terlebih dahulu mempertimbangkan eksepsi Termohon

dan Pihak Terkait berkenaan dengan kewenangan Mahkamah, yang pada pokoknya menyatakan Mahkamah tidak berwenang mengadili permohonan a quo, dengan alasan Mahkamah hanya berwenang mengadili hal-hal yang berkaitan dengan perselisihan hasil sedangkan hal-hal selebihnya menjadi kewenangan lembaga lain. Terhadap eksepsi tersebut, setelah Mahkamah mempelajari objek permohonan dan Petitum permohonan Pemohon, ternyata yang dimohonkan oleh Pemohon di antaranya adalah permohonan pembatalan terhadap Keputusan Komisi Pemilihan Umum Kabupaten Sabu Raijua Nomor 342/HK.03.1-Kpt/5320/KPU-

$\mathrm{Kab} / \mathrm{XII} / 2020$ tentang Penetapan Rekapitulasi Hasil Penghitungan Suara Pemilihan Bupati dan Wakil Bupati Sabu Raijua Tahun 2020, bertanggal 16 Desember 2020.

[3.2] Menimbang bahwa Pasal 157 ayat (3) Undang-Undang Nomor 10 Tahun 2016 tentang Perubahan Kedua Atas UndangUndang Nomor 1 Tahun 2015 tentang Penetapan Peraturan Pemerintah
Pengganti Undang-Undang Nomor 1 Tahun 2014 tentang Pemilihan Gubernur, Bupati, dan Walikota Menjadi UndangUndang (UU 10/2016) menyatakan, "Perkara perselisihan penetapan perolehan suara tahap akhir hasil Pemilihan diperiksa dan diadili oleh Mahkamah Konstitusi sampai dibentuknya badan peradilan khusus". Selanjutnya, Pasal 157 ayat (4) UU 10/2016 menyatakan, "Peserta Pemilihan dapat mengajukan permohonan pembatalan penetapan hasil penghitungan perolehan suara oleh KPU Provinsi atau KPU Kabupaten/Kota kepada Mahkamah Konstitusi."

Bahwa berdasarkan uraian pertimbangan tersebut di atas, oleh karena telah ternyata permohonan para Pemohon di antaranya adalah berkaitan dengan perselisihan penetapan perolehan suara dan petitum para Pemohon di antaranya berkenaan dengan pembatalan terhadap Keputusan Komisi Pemilihan Umum Kabupaten Sabu Raijua Nomor 342/HK.03.1-Kpt/5320/KPU -Kab/XII/2020 tentang Penetapan Rekapitulasi Hasil Penghitungan Suara Pemilihan Bupati dan Wakil Bupati Sabu Raijua Tahun 2020, bertanggal 16 Desember 2020, maka dengan merujuk pada ketentuan Pasal 157 ayat (3) dan ayat (4) UU 10/2016 eksepsi Termohon dan Pihak Terkait tidak beralasan menurut hukum. Oleh karena itu, Mahkamah berwenang mengadili permohonan para Pemohon terkait.

\section{KESIMPULAN}

Dalam kasus ini dapat disimpulkan ketua Mahkamah Konstitusi Menyatakan permohonan para Pemohon tidak dapat diterima. Eksepsi Termohon dan Pihak Terkait mengenai kewenangan Mahkamah tidak beralasan menurut hukum. Mahkamah berwenang mengadili permohonan a quo. Eksepsi Termohon dan Pihak Terkait mengenai kedudukan hukum para Pemohon beralasan menurut hukum. Para Pemohon tidak memiliki kedudukan hukum untuk mengajukan permohonan yang terkait. Eksepsi lain dari Termohon dan Pihak Terkait, tenggang waktu pengajuan permohonan dan pokok permohonan serta hal-hal lain yang berkaitan dengan permohonan terkait, tidak dipertimbangkan. 


\section{DAFTAR PUSTAKA}

a. Laporan Penelitian

Ridwan arifin (program studi pascasarjana,fakultas hukum Universitas Gadjah mada, yogyakarta) laporan peneltian menganai analisis hukum internasional dalam perampasan aset di negara kawasan asia tenggara berdasarkan united nations convention against corruption (UNCAC) dan asean mutuallegal assistance treaty (AMLAT).

b. Sumber Internet

Anwar usman (ketua Mahkamah Konstitusi)15/4/2021.(CNN indonesia)

Aida Mardatillah (HukumOnline.com) 16 April 2021

PDF Salinan putusan mahkamah konstitusi (google)

Ahli Dr. Maruarar Siahaan, S.H. (dalam pdf salinan putusan Mahkamah konstitusi) 